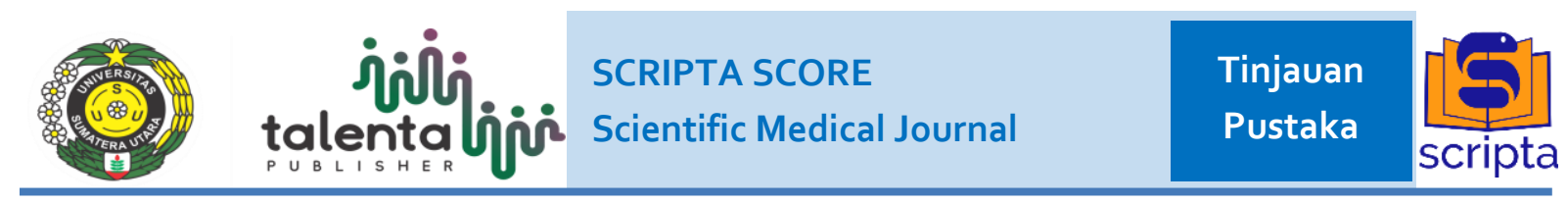

\title{
Obesitas dengan Kanker Kolorektal, Bagaimana Keterkaitan Keduanya?
}

\author{
Ridwan Balatif, Nenni Dwi Aprianti Lubis \\ Departemen Ilmu Gizi, Fakultas Kedokteran, Universitas Sumatera Utara, Medan
}

\begin{abstract}
ABSTRAK
Latar Belakang: Obesitas sampai saat ini masih menjadi permasalahan kesehatan yang sering terjadi. Kondisi obesitas ini bahkan mengalami peningkatan baik secara global maupun nasional. Peningkatan kasus obesitas ini dikhawatirkan akan meningkatkan kondisi penyakit lain seperti kanker kolorektal. Tujuan: Artikel ini akan memberikan pemaparan mengenai kaitan obesitas dengan kejadian kanker kolorektal sehingga dapat memberikan gambaran terkini yang mudah dipahami mengenai obesitas dan kanker kolorektal. Metode: Artikel ini ditulis dengan menggunakan metode pencarian literatur. Sumber informasi diambil dari E-book, website, dan search engine. Informasi yang diambil dalam rentang tahun 2013-2020. Pembahasan: Diduga obesitas dengan melalui proses inflamasi kronik akan mengakibatkan kerusakan DNA sel sehingga berisiko mencetuskan kanker. Sampai saat ini terdapat 13 jenis kanker yang berkaitan erat dengan kejadian obesitas. Kondisi obesitas ini selain akan meningkatkan risiko seseorang untuk mengalami kanker kolorektal, juga dapat meningkatkan risiko kematian pada individu yang mengalami kanker kolorektal dengan obesitas. Kesimpulan: Kondisi obesitas meningkatkan risiko kejadian dan mortalitas kasus kanker kolorektal.
\end{abstract}

Kata Kunci: kanker, obesitas, pencarian literatur

\section{ABSTRACT}

Background: Obesity is still a frequent health problem. This condition of obesity has even increased both globally and nationally. It is feared that the increase in obesity cases will increase other disease conditions such as colorectal cancer. Objectives: This article will provide an overview of the relationship between obesity and the incidence of colorectal cancer so as to provide a current, easy-tounderstand picture of obesity and colorectal cancer. Methods: This article was written using the literature search method. Sources of information are taken from E-books, websites, and search engines. Information taken in the period 2013-2020. Discussion: It is suspected that obesity through a chronic inflammatory process will cause cell DNA damage so that it is at risk of triggering cancer. Until now, there are 13 types of cancer that are closely related to the incidence of obesity. This condition of obesity in addition to increasing a person's risk of developing colorectal cancer, it can also increase the risk of death in obese individuals with colorectal cancer. Conclusion: Obesity condition increases the risk of incidence and mortality of colorectal cancer cases.

Keywords: cancer, literature searching, obesity Received [12 Aug 2020] | Revised [11 Dec 2020] | Accepted [17 Dec 2020]

\section{PENDAHULUAN}

Obesitas merupakan kondisi akumulasi lemak yang berlebihan yang dapat mengganggu kesehatan. $^{[1]}$ Akumulasi lemak berarti adanya peningkatan jumlah serta ukuran dari sel-sel lemak di tubuh. Saat ini obesitas menjadi salah satu problematika kesehatan yang sering terjadi.

Secara global pada tahun 2016, diperkirakan 1,9 milyar orang dengan usia diatas 18 tahun mengalami berat badan berlebih (overweight, IMT 25,0-29,9 $\mathrm{kg} / \mathrm{m}^{2}$ ). Untuk obesitas (IMT $\geq 30 \mathrm{~kg} / \mathrm{m}^{2}$ ) diperkirakan dialami oleh 650 juta orang dengan usia diatas 18 tahun. ${ }^{[1]}$ Di Indonesia sendiri, berdasarkan Riset Kesehatan Dasar (RISKESDAS) pada tahun 2018 kejadian obesitas (IMT > $27 \mathrm{~kg} / \mathrm{m}^{2}$ ) mencapai $21,8 \%$, kejadian ini mengalami peningkatan dari tahun 2013 yang 
mencapai $14,8 \%$. Kejadian obesitas di Provinsi Sumatera Utara sendiri bahkan melebihi kejadian nasional yakni mencapai $25,8 \%$. $^{[2]}$

Kondisi obesitas ini dikhawatirkan akan meningkatkan risiko seseorang untuk mengalami berbagai penyakit seperti penyakit jantung koroner, hipertensi, sindrom metabolik, gangguan tidur hingga kanker. Bahkan diduga sekitar 20\% kejadian kanker berkaitan dengan kondisi obesitas ini. ${ }^{[3]}$ Salah satu jenis kanker yang berkaitan erat dengan obesitas ialah kanker kolorektal. Peningkatan BMI sebesar 5 $\mathrm{kg} / \mathrm{m}^{2}$ akan meningkatkan risiko kanker kolorektal sebesar 5\%. ${ }^{[4]}$

Hal ini tentunya sangat mengkhawatirkan mengingat kondisi obestas ini terus mengalami peningkatan maka risiko penyakit seperti kanker kolorektal akan mengalami peningkatan juga di masa mendatang.Artikel ini bertujuan untuk memaparkan kondisi obesitas yang dapat mempengaruhi kejadian kanker kolorektal.

\section{METODE}

Penulisan metode ini menggunakan literature searching. Informasi diambil dari sumber E-book, website dan search engine. Sumber E-book yang digunakan adalah yang memuat informasi mengenai obesitas dan kanker kolorektal. Dalam hal pencarian data prevalensi obesitas, sumber utama yang digunakan berasal dari Kementerian Kesehatan dan WHO. Untuk pencarian informasi dari penelitian terbaru yang memiliki rentang waktu 2013-2020. Pencarian informasi menggunakan search engine berupa Pubmed, Google Scholar, dan Google dengan menggunakan kata kunci "obesity", "colorectal cancer" "kanker kolorektal DAN obesitas" dan "obesity AND colorectal cancer".

\section{PEMBAHASAN}

\section{Obesitas}

Akumulasi berlebihan sel-sel lemak di dalam tubuh memicu terjadinya kondisi yang disebut obesitas. Untuk mengklasifikasikan status nutrisi seseorang menggunakan perhitungan Indeks Massa Tubuh (IMT) atau Body Mass Index (BMI). Perhitungan IMT $\left(\mathrm{kg} / \mathrm{m}^{2}\right)$ diketahui dari berat seseorang (dalam $\mathrm{kg}$ ) dibagi tinggi badan kuadrat (dalam meter). ${ }^{[1]}$ Saat ini klasifikasi dari IMT mengacu pada kriteria WHO dan Asia Pasifik. Di Indonesia, oleh Kementerian Kesehatan juga memiliki klasifikasi IMT sendiri. Klasifikasi IMT tersebut disajikan pada Tabel 1.

Obesitas merupakan masalah kesehatan yang kompleks hingga saat ini. Diperkirakan pada tahun 2030, sekitar 38\% populasi orang dewasa di dunia akan mengalami overweight dan $20 \%$ populasi mengalami obesitas. ${ }^{[7]}$ Penelitian NCD Risk Factor Collaboration mendapatkan bahwa dari tahun 1975-2016 terjadi peningkatan prevalensi obesitas di banyak negara. Secara global terjadi peningkatan prevalensi obesitas dari $0,7 \%$ pada tahun 1975 menjadi 5,6\% pada tahun 2016 untuk anak perempuan sedangkan pada anak lakilaki peningkatan terjadi dari $0,9 \%$ pada tahun 1975 menjadi $7,8 \%$ pada tahun $2016 .^{[8]}$

Tabel 1. Klasifikasi $\operatorname{IMT}^{[5,6]}$

\begin{tabular}{cccc}
\hline Klasifikasi & WHO & Asia Pasifik & Nasional \\
\hline Underweight & $<18,5$ & $<18,5$ & $\begin{array}{c}\text { Mild }(17,0-18,4) \\
\text { Severe }(<17,0)\end{array}$ \\
\hline Normoweight & $18,5-24,9$ & $18,5-22,9$ & $18,5-25,0$ \\
\hline Overweight & $25,0-29,9$ & $23-24,9$ & $25,1-27,0$ \\
\hline Obesitas & $\geq 30$ & $\geq 25$ & $>27$ \\
\hline
\end{tabular}


Penyebab dari overweight dan obesitas adalah akibat ketidakseimbangan energi antara asupan kalori dengan kalori yang diperlukan oleh tubuh. ${ }^{[1,9]}$ Secara umum, peningkatan asupan dari makanan tinggi kalori seperti tinggi lemak ataupun gula serta adanya peningkatan gaya hidup yang sedenter meningkatkan risiko terjadinya obesitas. ${ }^{[1]}$ Saat ini konsumsi makanan cepat saji setiap harinya mengalami peningkatan pada $30 \%$ anak dan 50\% pada mahasiswa. Makanan cepat saji miskin akan mikronutrien, rendah serat, tinggi energi dan tinggi gula sehingga mengonsumsi makanan tersebut dapat memberikan jumlah energi yang melebihi dari yang tubuh perlukan. ${ }^{[10]}$ Kelebihan energi inilah dapat meningkatkan jumlah lemak didalam tubuh. Contoh makanan cepat saji seperti sandwich, pizza, makanan berlemak, burger, makanan yang digoreng, selain itu minuman yang memiliki pemanis seperti soda, sirup dan minuman energi.

Selain itu, faktor genetik dianggap dapat meningkatkan risiko terjadinya obesitas. Seorang anak yang terlahir dari kedua orang tua yang obesitas memiliki risiko sebesar $80 \%$ mengalami obesitas juga. Apabila salah satu orang tua mengalami obesitas, maka kejadian anaknya mengalami obesitas sebesar $40 \%$ dan jika kedua orang tuanya tidak obesitas maka risiko terjadinya obesitas pada anaknya sebesar $14 \% .{ }^{[11]}$

\section{Kanker Kolorektal}

Kanker didefinisikan sebagai proliferasi atau perbanyakan sel secara berlebihan (abnormal) dan dapat menginvasi bagian tubuh sekitar sel tersebut serta dapat berpindah ke organ lain (metastasi). Saat ini kanker merupakan penyebab kematian nomor dua didunia dengan estimasi 9,6 juta kematian pada tahun 2018. Secara umum, sekitar 1 dari 6 kematian diakibatkan oleh kanker. Sekitar 1/3 kematian pada kanker diakibatkan gaya hidup yang tidak sehat seperti memiliki IMT yang tinggi, asupan buah dan sayur yang rendah, kurang aktivitas fisik, merokok dan konsumsi alkohol. ${ }^{[12]}$

Kanker terjadi karena adanya gangguan genetik akibat mutasi pada DNA sel. Perubahan genetik yang mengakibatkan kanker ini dapat diturunkan dari orang tua ke anaknya sehingga dapat meningkatkan risiko terjadi kanker pada anaknya. Selain itu, faktor lingkungan dapat meningkatkan risiko terjadinya kanker. Faktor lingkungan yang dimaksud dapat berupa diet yang tidak sehat (yang memicu obesitas), radiasi, asap rokok, sinar UV, konsumsi alkohol, agen infeksius. Faktor-faktor tersebut dapat memicu terjadinya kerusakan DNA yang menimbulkan kejadian kanker. ${ }^{[13,14]}$

Sekitar 20\% kejadian kanker berhubungan dengan obesitas. ${ }^{[3]}$ Kondisi overweight dan obesitas diperkirakan menyumbang sebesar $14 \%$ kematian pada pria dengan kanker dan 20\% kematian pada perempuan dengan kanker. ${ }^{[15]}$ Dugaan bahwa obesitas memicu kanker dikarenakan adanya proses inflamasi yang kronis sehingga memicu kerusakan DNA dan meningkatkan kemungkinan terjadinya mutasi sehingga kanker terjadi. ${ }^{[3]}$

Kanker kolorektal merupakan kanker atau keganasan yang terjadi pada jaringan usus besar dari kolon dan atau rektum. ${ }^{[16]}$ Pada tahun 2018, diperkirakan terdapat 1,8 juta kasus kanker kolorektal dengan kematian sebanyak 862.000 jiwa. Hal ini menjadikan kanker kolorektal sebagai penyumbang ketiga terbanyak kasus kanker dan penyumbang kematian kedua terbanyak pada pasien dengan kanker. ${ }^{[12]}$

Sekitar 5\% atau 1 dari 20 warga Amerika terdiagnosis kanker kolorektal. ${ }^{[17]}$ Seseorang berisiko dua kali lipat mengalami kanker kolorektal apabila orang tuanya terdiagnosis kanker kolorektal di usia 50-70 tahun dan risiko ini meningkat tiga kali lipat apabila orang tuanya terdiagnosis kanker kolorektal sebelum usia 50 tahun. ${ }^{[18]}$ Selain dari riwayat keluarga, peningkatan dari BMI juga dapat meningkatkan risiko terjadinya kanker kolorektal. $^{[19]}$ 


\section{Kanker dan Obesitas}

Laporan dari International Agency for Research on Cancer (IARC) Working Group on Body Fatness 2016 terdapat bukti yang cukup bahwa kegemukan berkaitan erat dengan 13 jenis kanker yakni adenokarsinoma esofagus, kolorektal, korpus uteri, lambung (kardiak), hati, kandung empedu, pankreas, payudara (postmenopause), ovarium, ginjal, meningioma, tiroid, multiple myeloma (Gambar 1). ${ }^{[19]}$

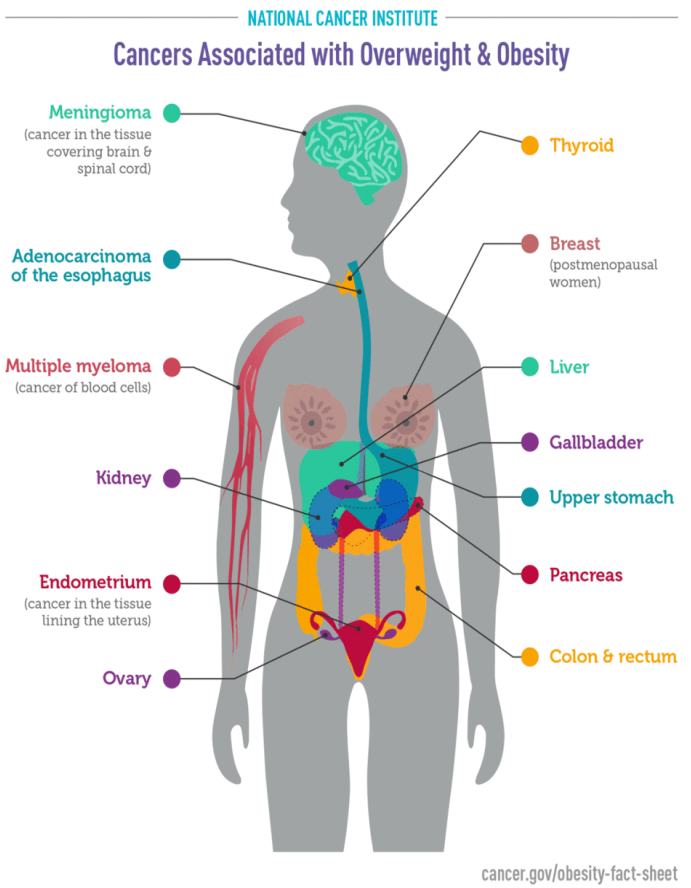

Gambar 1. Kanker yang berhubungan dengan kondisi overweight dan obesitas ${ }^{[21]}$

Secara umum, kondisi obesitas menimbulkan perubahan pada jaringan lemak yang dapat memicu terjadinya perubahan fisiologis sistemik yang meningkatkan risiko terjadinya kanker. Perubahan tersebut berupa perubahan kadar hormon dalam sirkulasi, adipokin, dan mediator inflamasi (Gambar 2). ${ }^{[20]}$

Pada orang dengan obesitas terjadi peningkatan kadar insulin dan insulin-like growth factor-1 (IGF-1) dalam darah (hiperinsulinemia atau resistensi insulin). ${ }^{[21]}$ Insulin dapat menghambat sintesis steroid-hormone binding globulin (SHBG). SHBG memiliki peranan penting dalam mengikat hormon seks seperti estradiol, testosteron, dihidrotestosteron. Terikatnya SHBG dengan hormon-hormon bebas itu akan membuat hormon tersebut menjadi inaktif. Apabila kadar SHBG rendah, akan mengakibatkan tingginya hormon-hormon tersebut didalam darah yang akan berefek hormon tersebut akan menstimulasi pertumbuhan reseptor estrogen dan androgen yang akan menginisiasi dan meningkatkan proliferasi pada kanker payudara dan prostat. ${ }^{[20]}$

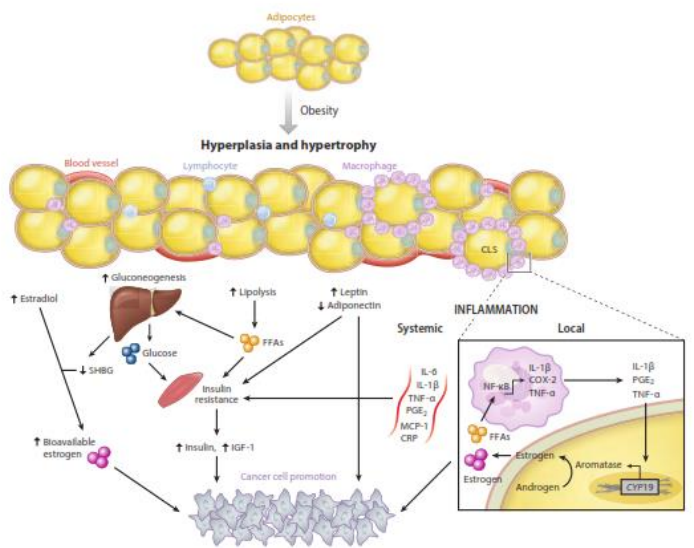

Gambar 2. Gangguan sistemik akibat abnormalitas jaringan lemak ${ }^{[20]}$

Sel lemak menghasilkan adipokin (leptin dan adiponektin), hormon yang dapat merangsang ataupun menghambat pertumbuhan sel. Peningkatan sel lemak di tubuh akan melepaskan leptin dalam jumlah lebih banyak ke dalam darah, efek leptin ini dapat meningkatkan pertumbuhan sel sehingga meningkatkan risiko seseorang (terutama pria) untuk mengalami adenoma kolon. Untuk adiponektin memiliki efek untuk menekan pertumbuhan yang berlebihan pada sel namun kadarnya rendah pada seseorang yang obesitas. ${ }^{[20,21]}$

Seseorang dengan obesitas mengalami kondisi inflamasi kronik, hal ditandai dengan meningkatnya kadar mediator proinflamasi yang memicu progresi tumor dan neoplasia. Kadar $C$-reactive protein (CRP) yang merupakan biomarker inflamasi umumnya mengalami peningkatan pada seseorang yang obesitas. Peningkatan kadar TNF- $\alpha$ dan IL-6 di sirkulasi dijumpai pada perempuan obesitas dan memiliki kaitan dengan perkembangan dan progresi kanker 
payudara. Selain itu, inflamasi sistemik ditandai dengan peningkatan metabolit Prostaglandin E-2 (PGE-2) di urin berkaitan dengan peningkatan terjadi kanker payudara pada perempuan yang menopause. ${ }^{[20]}$ Pada Tabel 2 memberikan informasi ringkasan risiko terjadinya kanker kolorektal pada individu dengan obesitas.

Tabel 2. Risiko kejadian kanker kolorektal pada individu dengan obesitas

\begin{tabular}{|c|c|c|}
\hline Studi & Hasil & Referensi \\
\hline Ma dkk (2013) & $\begin{array}{l}\text { Orang dengan obesitas } \rightarrow 1,334 \times \text { berisiko mengalami } \\
\text { kanker kolorektal }\end{array}$ & [22] \\
\hline Doleman dkk (2016) & $\begin{array}{l}\text { Pasien kanker kolorektal dengan underweight memiliki } \\
\text { risiko mortalitas } 1,43 \times \text { dan dengan obesitas memiliki risiko } \\
\text { mortalitas } 1,14 \times \text { dibandingkan pasien kanker kolorektal dan } \\
\text { BMI normal }\end{array}$ & [23] \\
\hline Daniel dkk (2016) & $\begin{array}{l}\text { Pasien kanker kolorektal yang terdiagnosis sebelum usia } 50 \\
\left.\text { tahun dengan obesitas kelas I (BMI } 30-34,9 \mathrm{~kg} / \mathrm{m}^{2}\right) \text { dan } \\
\left.\text { obesitas kelas II (BMI } \geq 35 \mathrm{~kg} / \mathrm{m}^{2}\right) \text { berisiko } 2-5 \times \text { mengalami } \\
\text { kematian dengan pasien } \text { overweight }\end{array}$ & [24] \\
\hline Liu dkk (2018) & $\begin{array}{l}\text { Perempuan dengan overweight } \rightarrow 1,37 \times \text { berisiko mengalami } \\
\text { kanker kolorektal } \\
\text { Perempuan dengan obesitas } \rightarrow 1,93 \times \text { berisiko mengalami } \\
\text { kanker kolorektal } \\
\text { Peningkatan } 5 \mathrm{~kg} / \mathrm{m}^{2} \rightarrow 1,20 \times \text { berisiko mengalami kanker } \\
\text { kolorektal }\end{array}$ & [25] \\
\hline Gu dkk (2018) & $\begin{array}{l}\text { Orang dengan overweight dan obesitas } \rightarrow 1,25 \times \text { dan } 1,57 \times \\
\text { berisiko mengalami kanker kolorektal }\end{array}$ & [26] \\
\hline Garcia dkk (2019) & $\begin{array}{l}\text { Pria dengan BMI tinggi berisiko } 1,39 \times \text { mengalami kanker } \\
\text { kolorektal dan perempuan dengan BMI tinggi berisiko } \\
1,19 \times \text { mengalami kanker kolorektal dibandingkan orang } \\
\text { dengan BMI normal }\end{array}$ & [27] \\
\hline
\end{tabular}

\section{KESIMPULAN}

Obesitas merupakan kondisi penimbunan sel lemak ditubuh. Kejadian obesitas setiap tahunnya mengalami peningkatan baik secara global maupun nasional. Kondisi obesitas sangat berkaitan erat dengan berbagai penyakit lain seperti penyakit kardiovaskular, diabetes hingga kanker. Diduga obesitas menimbulkan kerusakan DNA sel melalui proses inflamasi kronik. Saat ini terdapat 13 jenis kanker yang berhubungan erat dengan kejadian obesitas. Selain meningkatkan risiko terjadinya kanker tersebut, obesitas juga meningkatkan risiko mortalitas pada orang yang telah mengalami kanker. Oleh karena itulah, perlu kerjasama dari berbagai pihak seperti tenaga medis, ahli gizi, dukungan keluarga untuk bersama-sama dalam mengurangi kejadian obesitas ini.

\section{DAFTAR PUSTAKA}

[1] World Health Organization [Internet]. Obesity and Overweight. 2020 April [cited 2020 Aug 08]. Available from: https://www.who.int/newsroom/fact-sheets/detail/obesity-andoverweight

[2] Kementerian Kesehatan Republik Indonesia. Laporan Nasional RISKESDAS 2018. Jakarta: Kementerian Kesehatan Republik Indonesia; 2018.

[3] Meijers WC, de Boer RA. Common Risk Factors for Heart Failure and Cancer. Cardiovascular Research. 2019; 115(5): 844-853. doi: 10.1093/cvr/cvz035

[4] World Cancer Research Fund/American Institute for Cancer 
Research. World Cancer Research Fund International Systematic Literature Review: The Associations between Food, Nutrition and Physical Activity and the Risk of Colorectal Cancer. London; World Cancer Research Fund; 2017.

[5] Lim JU, Lee JH, Kim JS, et al. Comparison of World Health Organization and Asia-Pacific body mass index classifications in COPD patients. Int J Chron Obstruct Pulmon Dis. 2017;12:2465-2475. doi: 10.2147/COPD.S141295

[6] Kementerian Kesehatan Republik Indonesia [Internet]. Tabel Batas Ambang Indeks Massa Tubuh (IMT). 2019 June [cited 2020 Aug 08]. Available from: http://www.p2ptm.kemkes.go.id/info graphic-p2ptm/obesitas/tabel-batasambang-indeks-massa-tubuh-imt

[7] Hruby A, Hu FB. The Epidemiology of Obesity: A Big Picture. Pharmacoeconomics. 2015; 33(7): 673-689. doi:10.1007/s40273014-0243-X

[8] NCD Risk Factor Collaboration (NCD-RisC). Worldwide trends in body-mass index, underweight, overweight, and obesity from 1975 to 2016: a pooled analysis of 2416 population-based measurement studies in 128.9 million children, adolescents, and adults. Lancet. 2017; 390(10113): 2627-2642. doi:10.1016/S0140-6736(17)32129$\underline{3}$

[9] Adriani M, Wirjatmadi B. Pengantar Gizi Masyarakat. Jakarta: Kencana; 2016

[10] Mohammadbeigi A, Asgarian A, Moshir E, et al. Fast food consumption and overweight/obesity prevalence in students and its association with general and abdominal obesity. J Prev Med Hyg. 2018; 59(3): $\quad$ E236-E240. doi:10.15167/24214248/jpmh2018.59.3.830
[11] Utami CT. Konsumsi Susu Formula Sebagai Faktor Risiko Kegemukan Pada Balita di Kota Semarang. Skripsi. Universitas Diponegoro; Semarang: 2016

[12] World Health Organization [Internet]. Cancer. 2018 Sept [cited 08 August 2020]. Available from: https://www.who.int/newsroom/fact-sheets/detail/cancer

[13] Kumar V, Abbas AK, Aster JC. Robbins Basic Pathology. 10 ${ }^{\text {th }}$ ed. Philadelphia: Elsevier; 2018

[14] National Cancer Institute [Internet]. About Cancer. 2020 [cited 2020 Aug 09]. Available from: https://www.cancer.gov/aboutcancer

[15] Maratos-Flier E. Obesity. In: Melmed S, Auchus RJ, Goldfine AB, Koenig RJ, Rosen CJ. Williams Textbook of Endocrinology. $14^{\text {th }}$ ed. Philadelphia: Elsevier; 2020

[16] Kementerian Kesehatan Republik Indonesia. Panduan Penatalaksanaan Kanker Kolorektal. Jakarta: Kementerian Kesehatan RI; 2018

[17] American Cancer Society. Colorectal Cancer Facts \& Figures 2014-2016

[18] Kuipers EJ, Grady WM, Lieberman D, et al. Colorectal cancer. Nat Rev Dis Primers. 2015;1:15065. doi: 10.1038/nrdp.2015.65

[19] Lauby-Secretan B, Scoccianti C, Loomis D, Groose Y, Bianchini F, Straif K. Body Fatness and Cancer-Viewpoint of the IARC Working Group. N Engl J Med. 2016; 375(8): 794-798. doi:10.1056/NEJMsr1606602

[20] Iyengar NM, Hudis CA, Dannenberg AJ. Obesity and cancer: local and systemic mechanisms. Annu Rev Med. 2015; 66: 297-309. doi:10.1146/annurev-med-050913$\underline{022228}$

[21] National Cancer Institute [Internet]. Obesity and Cancer. 2017 Jan [cited 09 August 2020]. Available from: https://www.cancer.gov/about- 
cancer/causes-

prevention/risk/obesity/obesity-factsheet

[22] Ma Y, Yang Y, Wang F, et al. Obesity and risk of colorectal cancer: a systematic review of prospective studies. PLoS One. 2013;8(1):e53916. doi:10.1371/journal.pone.0053916

[23] Doleman B, Mills KT, Lim S, Zelhart MD, Gagliardi G. Body mass index and colorectal cancer prognosis: a systematic review and meta-analysis. Tech Coloproctol. 2016 Aug;20(8):517-35. doi: 10.1007/s10151-016-1498-3

[24] Daniel CR, Shu X, Ye Y, et al. Severe obesity prior to diagnosis limits survival in colorectal cancer patients evaluated at a large cancer centre. $\mathrm{Br}$ J Cancer. 2016;114(1):103-109. doi:10.1038/bjc.2015.424

[25] Liu $\mathrm{PH}, \mathrm{Wu} \mathrm{K}, \mathrm{Ng} \mathrm{K}$, et al. Association of Obesity With Risk of Early-Onset Colorectal Cancer Among Women. JAMA Oncol. 2019;5(1):37-44. doi: $\underline{10.1001 / \text { jamaoncol.2018.4280 }}$

[26] Gu MJ, Huang QC, Bao CZ, et al. Attributable causes of colorectal cancer in China. BMC Cancer. 2018;18(1):38. Published 2018 Jan 5. doi: $10.1186 / \mathrm{s} 12885-017-3968-\mathrm{Z}$

[27] Garcia H, Song M. Early-life obesity and adulthood colorectal cancer risk: a meta-analysis. Rev Panam Salud Publica. 2019;43:e3. Published 2019 Jan 4. doi: 10.26633/RPSP.2019.3 